7. Reprod. Fert. (1967) 14, 393-399

\title{
PROPERTIES OF DECAPACITATION FACTOR AND PRESENCE IN VARIOUS SPECIES
}

\author{
W. RICHARD DUKELOW, ${ }^{*}$ H. N. CHERNOFF* AND W. L. WILLIAMS \\ Department of Biochemistry, University of Georgia, \\ Athens, Georgia, U.S.A.
}

(Received 22nd August 1966)

\begin{abstract}
Summary. Seminal plasma from eight species was assayed for decapacitation factor (DF) activity. Seminal plasma from the bull, boar, stallion, rabbit and monkey all contained DF activity whereas human, rooster and dog seminal plasma did not. The hypothesis is suggested that the presence, or absence, of $\mathrm{DF}$ in the seminal plasma of a species is indicative of the need for, or lack of, capacitation within that species. Incubation of partially purified DF with hyaluronidase, glucose oxidase, lysozyme or Pronase does not affect DF activity; however, such activity was destroyed by incubation with $\alpha$-or $\beta$-amylase. Sialic acid, sialyl lactose and maltose were all ineffective in causing decapacitation or in preventing subsequent decapacitation of uterine sperm.
\end{abstract}

\section{INTRODUCTION}

In 1951 the necessity of a uterine incubation period for spermatozoa (capacitation) was demonstrated in the rabbit and rat in two laboratories independently (Austin, 1951; Chang, 1951). Since that time evidence has been presented suggesting that capacitation occurs in the hamster (Chang \& Sheaffer, 1957), mouse (Braden \& Austin, 1954), cow (Trimberger, 1948), ferret (Chang \& Yanagimachi, 1963) and sheep (Mattner, 1963). In 1957, Chang demonstrated the presence of a substance (decapacitation factor, DF) in seminal plasma capable of functionally reversing the capacitation process. Bedford \& Chang (1962) demonstrated that DF could be sedimented by ultracentrifugation. Since that time, work in this laboratory has concentrated on the purification and identification of DF (Weinman \& Williams, 1964; Dukelow, Chernoff \& Williams, 1966a, b; Chernoff, Pinsker, Dukelow \& Williams, 1966).

This paper reports the distribution of DF activity in the seminal plasma of eight species and describes attempts to destroy the DF activity of rabbit and bull seminal plasma by enzymatic techniques. Attempts to decapacitate uterine spermatozoa in vitro using sialic acid, sialyl lactose and maltose are also reported.

\section{MATERIALS AND METHODS}

Semen was collected from rabbits, bulls and stallions using the artificial vagina, from boars by the gloved hand technique, from monkeys by electro-ejaculation

* Present address: Oregon Regional Primate Research Center, Beaverton, Oregon, U.S.A. 
and from humans, roosters and dogs by manipulation. Spermatozoa were removed by centrifugation at $860 \mathrm{~g}$ for $30 \mathrm{~min}$. The seminal plasma was frozen and held at $-18^{\circ} \mathrm{C}$ until assayed for DF activity. Monkey semen required 3:1 dilution with calcium-free Krebs-Ringer phosphate solution (KRP) before centrifugation due to high viscosity. Partially purified DF was prepared by the method of Weinman \& Williams (1964) (DF pellet) from seminal plasma and assayed for DF activity. In all other species whole seminal plasma was assayed. The assay procedure used is illustrated in Text-fig. 1. Capacitated spermatozoa were recovered from the uterus of a doe (capacitator) $11 \mathrm{hr}$ after mating. These spermatozoa were divided into treatment and control tubes and the treatment spermatozoa were incubated with DF pellet or seminal plasma for $20 \mathrm{~min}$ at $37^{\circ} \mathrm{C}$ at a level of $5 \mathrm{mg}$ biuret-reactive-material (BRM) $/ 10^{5}$ spermatozoa.

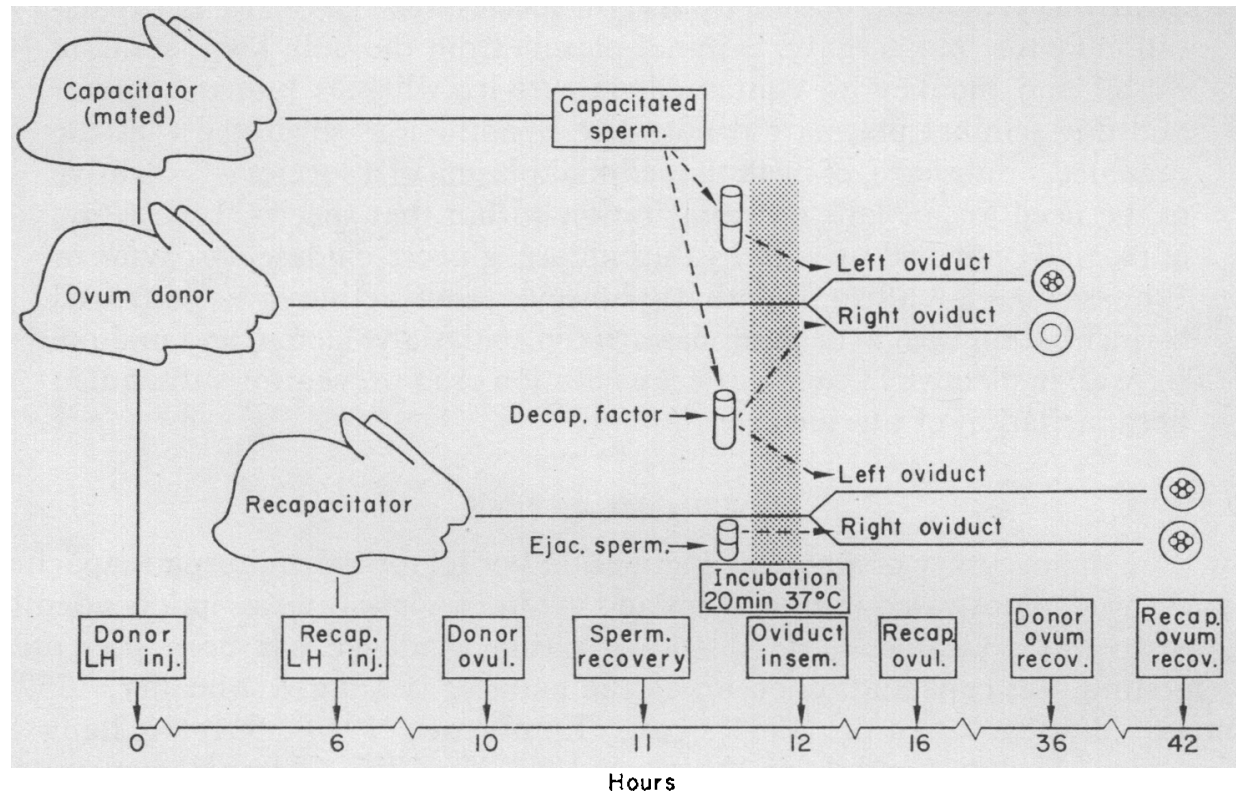

TEXT-FIG. 1. Schematic diagram of $\mathrm{DF}$ and recapacitation assay procedures used.

Previous work with bull DF preparations and rabbit seminal plasma had indicated that these substances possess DF activity at a level of $1 \mathrm{mg}$ BRM/10 spermatozoa; therefore, this level was used with these preparations. Spermatozoa $\left(2.5 \times 10^{4}\right)$ were inseminated into one oviduct $12 \mathrm{hr}$ after an ovulatory dose (3.1 mg) of luteinizing hormone (LH, Armour-Baldwin Pharmaceuticals) had been administered intravenously. The opposite oviduct received an equal number of spermatozoa not incubated with seminal plasma or DF pellet.

In cases of suspected spermatozoan toxicity and to insure that the decapacitated spermatozoa were capable of a second capacitation in utero (recapacitation), approximately $8 \times 10^{5}$ spermatozoa were injected into the uterine horn of a doe $6 \mathrm{hr}$ after LH injection (i.e. approximately $4 \mathrm{hr}$ pre-ovulation). In the opposite uterine horn a similar number of twice-washed ejaculated spermatozoa were injected to insure the doe's ability to capacitate spermatozoa. All 
does were killed $26 \mathrm{hr}$ or less after ovulation when fertile ova would be expected to be in the four-cell stage of cleavage (Austin, 1963).

Assays for the ability of various enzymes to destroy DF activity were conducted as previously described by Dukelow et al. (1966b). All incubations were conducted at $37^{\circ} \mathrm{C}$ and at an enzyme concentration of $100 \mu \mathrm{g} / 5 \mathrm{mg}$ BRM. Vibrio cholera filtrate (crude neuraminidase-lecithinase) was assayed at a level of $34 \mu \mathrm{g}$ due to extreme toxicity of the enzyme to spermatozoa. All incubations were for $2 \mathrm{hr}$ except with amylolytic enzymes where $\beta$-amylase destruction of $\mathrm{DF}$ in seminal plasma was found to require only $10 \mathrm{~min}$ but required up to $6 \mathrm{hr}$ with DF pellet. Enzymes tested were purchased from the following sources: $\beta$-amylase (General Biochemicals and N.B.C.); $\alpha$-amylase (General Biochemicals); lysozyme (Worthington Biochem.); glucose oxidase (Worthington Biochem.); hyaluronidase (General Biochemicals); Vibrio cholera filtrate (Sigma) and Pronase (Calbiochem. Co.).

Attempts to decapacitate or alternatively to prevent subsequent decapacitation of uterine spermatozoa by treatment with sialic acid (SA) and sialyl lactose (SL) were conducted by incubating uterine spermatozoa with SA $\left(1 \cdot 1 \mu \mathrm{g} / 10^{5}\right.$ spermatozoa) or sL $\left(2.4 \mu \mathrm{g} / 10^{5}\right.$ spermatozoa) for $15 \mathrm{~min}$ at $37^{\circ} \mathrm{C}$. These levels were equivalent to $10 \%$ of the amount of sialic acid normally occurring in seminal plasma. These spermatozoa were then incubated for $20 \mathrm{~min}$ at $37^{\circ} \mathrm{C}$ with DF pellet and assayed as illustrated in Text-fig. 1. Similarly, capacitated spermatozoa were incubated with maltose $\left(3.2 \mathrm{mg}\right.$ maltose $/ 10^{6}$ spermatozoa) to determine if decapacitation occurred.

All rabbits used were of the New Zealand White breed, virgin and $6 \frac{1}{2}$ to 7 months of age. Portions of this work were published in a preliminary report (Dukelow, Chernoff, Pinsker \& Williams, 1966).

\section{RESULTS}

The presence or absence of DF activity in seminal plasma of different species is shown in Table 1. Bull, rabbit, boar, stallion and monkey seminal plasma all have DF activity. Rooster, dog and human seminal plasma were devoid of DF activity at the levels tested.

The effects of various enzymes used to destroy DF activity in seminal plasma, partially purified DF, or both, are indicated in Table 2 . Hyaluronidase, glucose oxidase and lysozyme failed to destroy DF activity. $\beta$-Amylase destroyed DF activity in rabbit seminal plasma after $10 \mathrm{~min}$ incubation. Using DF pellet, 6 to $13 \mathrm{hr}$ incubation were required to destroy DF activity. $\alpha$-Amylase partially destroyed DF activity but not as effectively as $\beta$-amylase. None of the enzymes assayed were toxic to the spermatozoa at the $100 \mu \mathrm{g}$ level except $V$. cholera filtrate. At a non-toxic level ( $34 \mu \mathrm{g} / 5 \mathrm{mg}$ BRM) this crude enzyme preparation did not destroy DF activity.

Soupart \& Clewe (1965) have indicated a role of sialic acid in the reproductive process. Work in this laboratory has indicated a level of $1.26 \mu \mathrm{g}$ sialic acid/ $2.5 \mathrm{mg}$ dry weight of a Pronase digested DF active fraction (Chernoff et al., 1966). Sialic acid and sialyl lactose were assayed for their ability to decapacitate or prevent subsequent decapacitation of uterine spermatozoa at approximately 
that level. The results are shown in Table 3. Treatment of uterine spermatozoa at the levels indicated did not interfere with the fertility of the spermatozoa, nor did it prevent their subsequent decapacitation after incubation with DF pellet. Capacitated spermatozoa treated with maltose were not decapacitated (Table 3).

TABLE 1

DF AGTIVITY IN THE SEMINAL PLASMA OF VARIOUS SPEGIES

\begin{tabular}{|c|c|c|c|c|}
\hline \multirow{2}{*}{ Species } & \multirow{2}{*}{$\begin{array}{c}\text { Demonstrated need } \\
\text { for capacitation in } \\
\text { literature }\end{array}$} & \multirow{2}{*}{$\begin{array}{c}\text { No. } \\
\text { rabbits }\end{array}$} & \multicolumn{2}{|c|}{ Percent. and No. of ova fertilized } \\
\hline & & & Capac. sperm. control & Capac. sperm. $+D F$ \\
\hline $\begin{array}{l}\text { Bull* } \\
\text { Rabbit } \\
\text { Monkey } \\
\text { Stallion } \\
\text { Boar }\end{array}$ & $\begin{array}{l}+ \\
+ \\
+ \\
+\end{array}$ & $\begin{array}{r}57 \\
12 \\
4 \\
7 \\
7\end{array}$ & $\begin{array}{l}54 \cdot 8(172) \\
87 \cdot 4(48) \\
70 \cdot 0(10) \\
85 \cdot 2(27) \\
35 \cdot 8(28)\end{array}$ & $\begin{array}{ll}0 & (134) \\
0 & (38) \\
0 & (12) \\
0 & (26) \\
0 & (19)\end{array}$ \\
\hline $\begin{array}{l}\text { Human } \\
\text { Dog } \\
\text { Rooster }\end{array}$ & - & $\begin{array}{r}16 \\
7 \\
6\end{array}$ & $\begin{array}{l}53 \cdot 3(62) \\
63 \cdot 2(19) \\
66 \cdot 7(24)\end{array}$ & $\begin{array}{l}24 \cdot 1(54) \\
32 \cdot 3(31) \\
42 \cdot 2(19)\end{array}$ \\
\hline
\end{tabular}

* Assayed as a DF pellet, $1 \mathrm{mg}$ BRM/ $10^{5}$ spermatozoa.

† Assayed at $2 \mathrm{mg}$ BRM/10 $/ 10^{5}$ spermatozoa.

TABLE 2

ENZYMATIC DESTRUCTION OF DF AGTIVITY

\begin{tabular}{|c|c|c|c|}
\hline \multirow{2}{*}{ Enzyme } & \multicolumn{3}{|c|}{ Percent. and No. of ova fertilized } \\
\hline & Capac. sperm. control & $\begin{array}{c}\text { Capac. sperm. } \\
\text { enzyme }\end{array}$ & $\begin{array}{c}\text { Capac. sperm. }+ \text { sem. plasma }+ \\
\text { enzyme }\end{array}$ \\
\hline $\begin{array}{l}\alpha \text {-Amylase } \\
\beta \text {-Amylase } \\
\text { Glucose oxidase } \\
\text { Hyaluronidase } \\
\text { Lysozyme } \\
V \text {. cholera filtrate } \\
\text { Pronase }\end{array}$ & $\begin{array}{l}59 \cdot 5(37) \\
50 \cdot 8(116) \\
63.7(11) \\
37.6(8) \\
62.2(37) \\
57 \cdot 1(49) \\
46.2(13)\end{array}$ & $\begin{array}{cl}5 \cdot 9 & (17) \\
26 \cdot 2 & (42)^{*} \\
0 & (13) \\
0 & (4) \\
0 & (10) \\
& - \\
0 & (6)\end{array}$ & 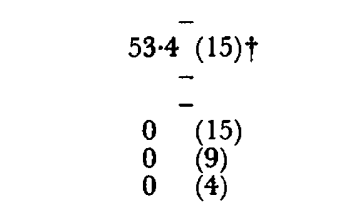 \\
\hline
\end{tabular}

All enzymes tested at $100 \mu \mathrm{g} / 5 \mathrm{mg}$ BRM except V.C. filtrate tested at $34 \mu \mathrm{g}$ due to toxicity. * 6 to $12 \mathrm{hr}$ incubation at $37^{\circ} \mathrm{C}$.

$+10 \mathrm{~min}$ incubation at $37^{\circ} \mathrm{C}$.

TABLE 3

EFFEGT OF SIALIC ACID, SIALYL LACTOSE, AND MALTOSE ON CAPAGITATED SPERMATOZOA

\begin{tabular}{l|c|c}
\hline \multicolumn{1}{c|}{ Treatment } & $\begin{array}{c}\text { No. of } \\
\text { ova }\end{array}$ & \begin{tabular}{c} 
Fertilization \\
\hline Negative control
\end{tabular} \\
Sialic acid $\left(1 \cdot 1 \mu \mathrm{g} / 10^{5}\right.$ spermatozoa) & 71 & 47.9 \\
Sialyl lactose $\left(2 \cdot 4 \mu \mathrm{g} / 10^{3}\right.$ spermatozoa) & 33 & $33 \cdot 3$ \\
Sialic acid-DF* & 14 & $45 \cdot 5$ \\
Maltose $\left(3 \cdot 2 \mathrm{mg} / 10^{6}\right.$ spermatozoa) & 14 & $57 \cdot 2$ \\
\hline
\end{tabular}

* S.A. and capacitated spermatozoa incubated $15 \mathrm{~min}$; then DF added for $20 \mathrm{~min}$ at $37^{\circ} \mathrm{C}$. 


\section{DISGUSSION}

\section{Presence of $D F$ in various species}

Weinman \& Williams (1964) have suggested that DF is the substance removed from the sperm head surface during the capacitation process. This would imply the presence of DF in the seminal plasma of those species which require capacitation. The need for capacitation has been suggested in the cow, ewe, rabbit, rat, ferret and mouse. In 1945, van Wagenen reported the optimum time for insemination in the monkey was from noon on Day 11 to noon of Day 12 of the menstrual cycle. Hartman (1933) reported the mean and modal ovulation date for this species was Day 13 of the cycle. This suggests that monkey spermatozoa also require a period of uterine incubation before fertilization of the ovum. The seminal plasma of the bull, rabbit and monkey all have DF activity.

If rooster spermatozoa require capacitation at all, the time is very short, 45 min or less (Marion \& Williams, unpublished data). The present study failed to demonstrate DF activity in rooster semen and would support the hypothesis that the presence of DF activity in the seminal plasma of any species is indicative of the need for capacitation by that species. Further confirmation or rejection of this hypothesis would come with the demonstration of the need for or lack of capacitation in the dog or human.

According to this hypothesis, capacitation of human spermatozoa would not be required since DF was not detected in human seminal plasma. This is interesting since the seminal plasma of the other primate studied (Rhesus) did contain DF. A second possible interpretation which must be considered is that DF is present in human seminal plasma but is sufficiently different from rabbit DF as to be ineffective in decapacitating rabbit spermatozoa, i.e. that human DF is species specific and will not decapacitate rabbit spermatozoa but capacitation is still required in humans.

Chang (1957) failed to reverse completely capacitation of rabbit spermatozoa with human seminal plasma when tested at approximate levels from 1.5 to 2.8 mg BRM $/ 10^{5}$ spermatozoa although he suggested DF was present due to the lowered $(27 \%)$ fertility of seminal plasma-treated spermatozoa compared to the control spermatozoa ( $78 \%$ fertility).

The species-specificity of the capacitation process itself has never been demonstrated; however, recently, Bedford \& Shalkovsky (1967) have suggested that a part of the capacitation phenomena of rabbit spermatozoa can be carried out in the rat.

\section{Enzymatic digestion of $D F$}

It has been previously demonstrated that the amylase content of the uterine fluid is elevated at the time when capacitation normally occurs and that $\beta$-amylase preparations will destroy the DF activity of seminal plasma (Dukelow et al., 1966a). The present study further demonstrates that crystalline commercial $\alpha$ - and $\beta$-amylase preparations will destroy the activity of partially purified DF. This adds support to the hypothesis that uterine amylase activity plays a role in the capacitation process. Failure of hyaluronidase, glucose oxidase, lysozyme and Pronase to destroy DF activity indicates that the linkages 
and structures such enzymes attack are not contained in DF or essential for DF activity. Chernoff et al. (1966) have presented evidence for the hydrolysis of peptide linkages in high molecular weight crude DF preparations with degradation to lower molecular weight active DF. The failure to destroy DF activity by proteolysis would indicate that the active moiety involved in decapacitation is not protein in nature. The elevated level of lysozyme-like enzymes in uterine fluid at the time of capacitation (Dukelow et al., 1966b) is apparently in response to the bacterial invasion associated with insemination since DF activity was not destroyed by this enzyme. Lysozyme does not appear to play a role in capacitation.

Sialic acid plays an important physiological role in binding disaccharides and polysaccharides to cell surfaces. Attempts to interfere with these binding sites on the sperm cell surface with sialic acid, sialyl lactose or maltose and thereby cause decapacitation or prevent subsequent decapacitation with DF were unsuccessful.

\section{ACKNOWLEDGMENTS}

The authors wish to thank the following for supplying seminal plasma from the species indicated: Dr W. E. Erickson, Tri-State Breeders Cooperative, Westby, Wisconsin (bull, boar); Dr W. Pickett, University of Connecticut, Storrs, Conn. (stallion, dog) and Dr Wm. Montagna and Dr Dale Hoskins, Oregon Regional Primate Research Center, Beaverton, Oregon (monkey). We also acknowledge the assistance of $\mathrm{Mr} \mathrm{J}$. L. Patrick in animal care and surgery. This work was supported by National Institute of Health Grant GM-10034.

\section{REFERENCES}

Austin, C. R. (1951) Observations on the penetration of the sperm into the mammalian egg. Aust. 7 . scient. Res. B, 4, 581 .

Austin, C. R. (1963) Conference on physiological mechanisms concerned with conception, p. 315. Pergamon Press, New York.

Bedford, J. M. \& Chang, M. C. (1962) Removal of decapacitation factor from seminal plasma by high speed centrifugation. Am. F. Physiol. 202, 179.

Bedford, J. M. \& Shalkovsky, R. (1967) Species specificity of sperm capacitation in the rabbit. 7. Reprod. Fert. 13, 361.

Braden, A. W. H. \& Austin, C. R. (1954) Fertilization of the mouse egg and the effect of delayed coitus and of hot-shock treatment. Aust. F. biol. Sci. 7, 552.

Ghang, M. C. (1951) Fertilizing capacity of spermatozoa deposited into the Fallopian tubes. Nature, Lond. 168, 697.

Chang, M. C. (1957) A detrimental effect of seminal plasma on the fertilizing capacity of sperm. Nature, Lond. 179, 258.

Ghang, M. C. \& Sheaffer, D. (1957) Number of spermatozoa ejaculated at copulation transported into the female tract, and present in the male tract of the Golden Hamster. F. Heredity, 48, 107.

Chang, M. G. \& Yanagimachi, R. (1963) Fertilization of ferret ova by deposition of epididymal sperm into the ovarian capsule with special reference to the fertilizable life of ova and the capacitation of sperm. 7. exp. Zool. 154, 175.

Chernoff, H. N., Pinsker, M. C., Dukelow, W. R. \& Williams, W. L. (1966) Purification of sperm antifertility factor. Fedn Proc. Fedn Am. Socs exp. Biol. 25, 284.

Dukelow, W. R., Chernoff, H. N., Pinsker, M. C. \& Williams, W. L. (1966) Enzymatic activities at the time of sperm capacitation. F. Dairy Sci. 49, 725.

Dukelow, W. R., Chernoff, H. N. \& Williams, W. L. (1966a) Enzymatic characterization of decapacitation factor. Proc. Soc. exp. Biol. Med. 121, 396.

Dukelow, W. R., Chernoff, H. N. \& Williams, W. L. (1966b) Stability of spermatozoan decapacitation factor. Am. J. Phvsiol. 211, 826. 
Hartman, C. (1933) Pelvic (rectal) palpation of the female monkey with special reference to the ascertainment of ovulation time. Am. F. Obstet. Gynec. 26, 600.

Mattner, P. E. (1963) Capacitation of ram spermatozoa and penetration of the ovine egg. Nature, Lond. 199, 772.

Soupart, P. \& ClewE, T. H. (1965) Sperm penetration of rabbit zona pellucida inhibited by treatment of ova with neuraminidase. Fert. Steril. 16, 677.

Trimberger, G. W. (1948) Breeding efficiency in dairy cattle from artificial insemination at various intervals before and after ovulation. Neb. Agr. Res. Bull. 153,

van Wagenen, G. (1945) Mating and pregnancy in the monkey. Anat. Rec. 91, 304.

Weinman, D. E. \& Williams, W. L. (1964) Mechanism of capacitation of rabbit spermatozoa. Nature, Lond. 203, 423. 